\title{
Gazelle Hunting Strategies in the Early Ahmarian: Close-Range Visuospatial Characteristics of Site Locations Indicate Spatially Focused Hunting Strategies on Gazella sp. During the Early Ahmarian
}

\author{
Florian Sauer $^{1} \mathbb{D}$. Jonathan Schoenenberg ${ }^{1}$ (D)
}

Accepted: 25 March 2021 / Published online: 13 July 2021

(c) The Author(s) 2021

\begin{abstract}
Visual conditions around Palaeolithic sites determine how the landscape was perceived by prehistoric hunter-gatherers. By placing the site in different landscapes, different visual foci were encoded in the locational characteristics of the different places. For the Early Ahmarian sites in the Levant, it can be shown that visual characteristics differ significantly with the combination of large ungulate prey exploited at the respective location. A Higuchi viewshed approach was combined with total viewsheds of the study area to introduce a human scale into the viewshed modelling. While diverse prey locations in the Mediterranean biome provide an overview over the landscape, specialised prey locations in the steppe biomes of the Irano-Turanian and Saharo-Arabian biome have their focus on the immediate vicinity of the sites. This correlates with the placement of sites in the context of highly humid environments which can be best exemplified with the site of Al-Ansab 1 in the escarpments of the Jordanian Rift Valley. Here, the environmental conditions acted as a magnet, focusing gazelles on the migration between different environments.
\end{abstract}

Keywords Early Ahmarian · Viewshed $\cdot$ Catchment $\cdot$ Gazelle $\cdot$ Modelling $\cdot$ Levant

\section{Introduction}

Given their recurrent and dominant presence in archaeological sites of the Early Ahmarian in the Levant, it is likely that their exploitation played an important role in human subsistence in the region (Rabinovich, 2003; Yeshurun et al., 2019)

Florian Sauer

Florian.sauer@uni-koeln.de

Jonathan Schoenenberg

j.schoenenberg@uni-koeln.de

1 Institute for Prehistory, University of Cologne, Cologne, Germany 
and that larger ungulates were the favoured prey in the available spectrum (Stiner, 2005). Contrasting the Early Upper Palaeolithic, data is much more abundant for the preceding Middle Palaeolithic as well as later periods (Rabinovich, 2003; Yeshurun et al., 2019). However, numerous sites (Fig. 1, Online Resource 1) of the Early Ahmarian cultural unit reflect the exploitation of small to mediumsized ungulates (Hooijer, 1961; Kuhn et al., 2009; Lieberman, 1995; Phillips, 1988; Rabinovich, 2003, 2017; Richter et al., 2020; Shea et al., 2019; Yeshurun et al., 2019). Particularly in the arid southern and south-eastern parts of the Early Ahmarian, steppic vegetation promotes the dominant presence of Gazella subgutturosa in the archaeological assemblages. This situation is contrasted by the dominance of deer (Dama mesopotamica) and mountain gazelles (Gazella gazella) in sites situated in the Mediterranean biome along the shores of the Mediterranean (Rabinovich, 2003). During the MIS 3 settlement between c. 46,000 a and 28,000 a cal BP, the extent of the Mediterranean biome (MB) was smaller than today, favouring the presence of arid environments like the Irano-Turanian (ITB) and Saharo-Arabian biomes (SAB) (Miebach et al., 2019). Both units promote
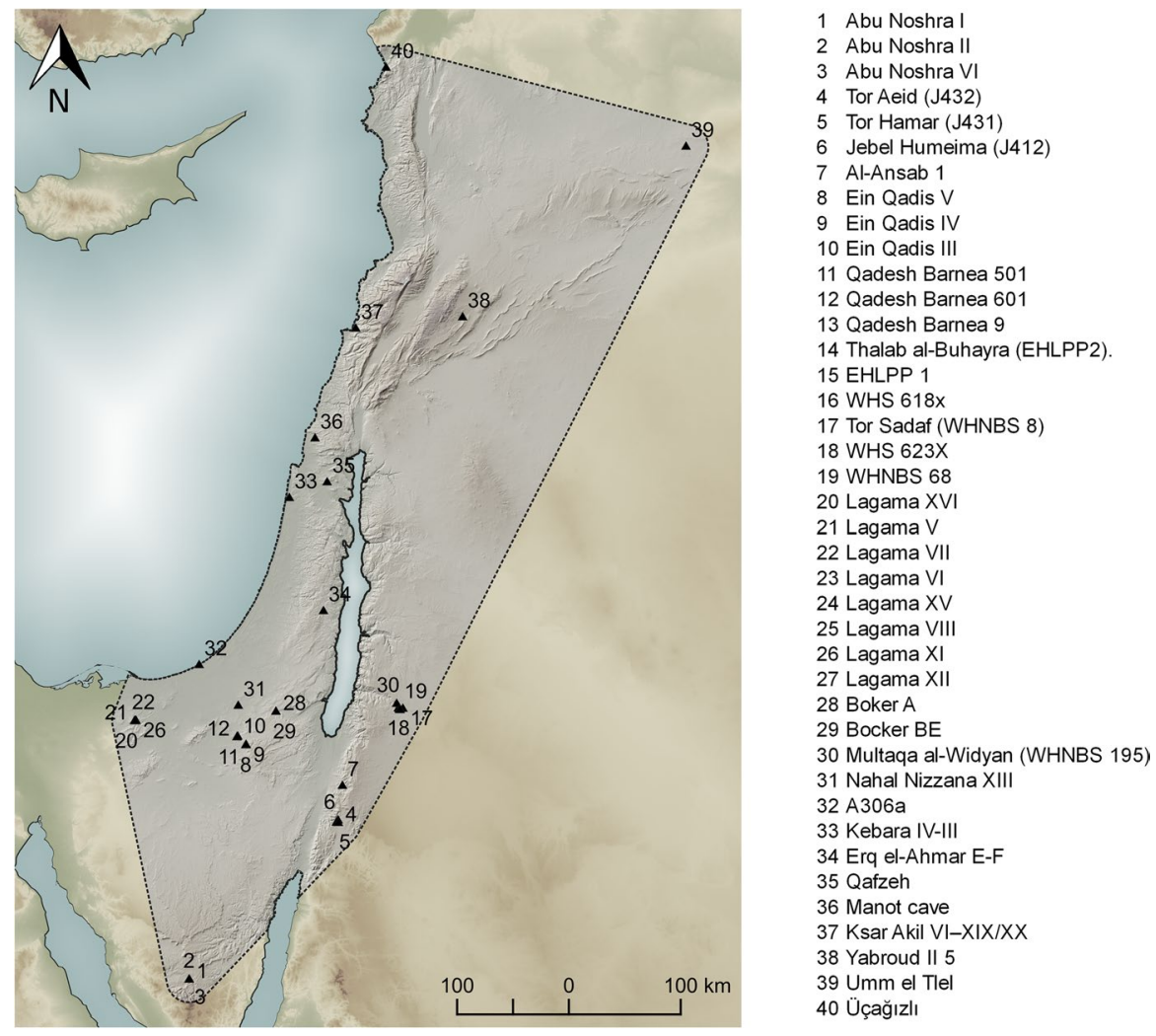

Fig. 1 Sites used for analysis in this paper and delineation of the study area (dotted line); the triangles represent the individual sites; numbering of sites is sorted ascending from south to north 
the presence of open vegetation in the landscape, while the Mediterranean biome supports the growth of forest patches and the fauna living therein (Miebach et al., 2019; Zohary, 1962).

Contrasting the behaviour of typical prey during the Upper Palaeolithic in Europe, some gazelle species are showing limited migratory behaviour with relatively small home ranges (Geffen et al., 1999; Yeshurun et al., 2019), whereas others show more expressed mobility (Martin, 2000). The predictability of gazelles in the landscape is relatively good, particularly due to the close tethering of the animals to water and plant resources (Khosravi et al., 2016). In the arid environment of the Levant during MIS 3 as well as today, the distribution of vegetation is closely related to the presence of water and humidity like lakes, streams or discharging aquifers. These conditions have played an important role in the distribution of gazelle herds in the landscape during mid-MIS 3. Consequently, this influenced the spatial behaviour of humans who set out to exploit the ungulates for the extraction of both food and raw material. This situation is partially reflected by the prevailing conditions around several Early Ahmarian sites in the Saharo-Arabian and Irano-Turanian biomes (e.g., Abu Noshra, Al-Ansab 1, Tor Hamar, Wadi al-Hasa) (Belmaker et al., 2014; Bouchud, 1974; Emery-Barbier, 1995; Henry, 1994; Parow-Souchon, 2020; Richter et al., 2020; Schuldenrein \& Clark, 2001; Williams, 2000). Here, the presence of lakes, marshes, or other advantageous conditions could be determined (Fig. 2).

The associated Early Ahmarian mobility pattern is considered to reflect residential mobility tethered to resource patches (Marks \& Friedel, 1983; Richter et al., 2020). This is reflected by low assemblage variability in terms of the toolset richness of different types of artefacts (Richter et al., 2020). Generally, high values of the Simpson diversity index (1-D) show the frequent execution of various tasks at the sites of the Early Ahmarian (Richter et al., 2020).

The assumption of tethered residential mobility suggests that the placement of sites by the bearers of the Early Ahmarian was related to spatial and environmental conditions in the landscape. Varying mobility of different prey species (Gazella gazella, Gazella subgutturosa and Dama mesopotamica) and the connection of humans to local affordances could have resulted in varying site locations.

Fig. 2 Sites with wetland or highly humid conditions in the periphery of the sites; triangles represent sites in highly humid contexts

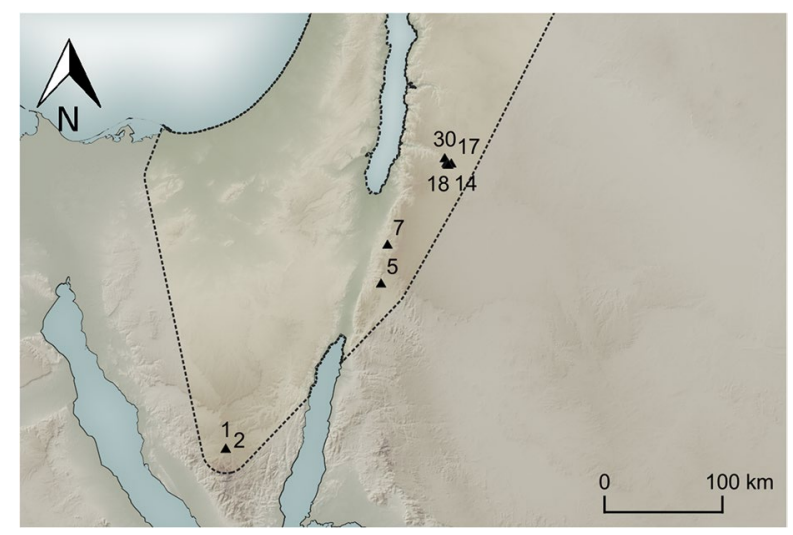


To investigate this question, we analyse the visuospatial (the visual properties of the landscape) conditions surrounding the sites of the Early Ahmarian in the Levant. The focus lies on the exploitation of one of the major prey species-Gazella sp. It remains clear that other species were exploited, too (Rabinovich, 2003). This is reflected particularly well by sites in the Mediterranean biome like Manot Cave, where Dama mesopotamica plays a more important role in human subsistence than the much smaller gazelles (Yeshurun et al., 2019). We employ a visual neighbourhood approach comparable to the one presented by Brughmans et al. (2018) using Higuchi viewsheds (Wheatley \& Gillings, 1999) to differentiate between the near- and far-field visibility of gazelles and equally sized objects in the landscape. This perception-oriented investigation aims to incorporate a human scale into the research. Different levels of mean visibility represent the variations in visual permeability (potential of perceiving the landscape by looking into it; analogous to locomotive permeability reflecting accessibility) of the landscape. Alongside this, different visual options arise from the observer's position, leading to an observation of the direct periphery or the far-field area. Assuming the non-random placement of sites by the human actors, we also assume that variations and patterns in visual contexts are interpretable as a conscious choice and can be related to human land use.

A point of origin for this research is the open-air site of Al-Ansab 1 in the Wadi Sabra (Klasen et al., 2013; Richter et al., 2020; Schyle et al., 2015). The Early Ahmarian site was investigated intensively within the Collaborative Research Centre 806 "Our Way to Europe" (CRC 806). As a secondary line of analysis, we aim to contextualise our current understanding of the settlement of Al-Ansab 1 with the more comprehensive analysis of regional visual properties of site locations of the Early Ahmarian.

\section{Material and Methods}

\section{The Site of Al-Ansab 1}

The open-air site of Al-Ansab 1 is situated in the Lower Wadi Sabra, c. $10 \mathrm{~km}$ south of the Nabataean capital of Petra. The Wadi Sabra opens into the Wadi Araba about $12 \mathrm{~km}$ to the West, while the headwaters allow access of the highlands about 15 to $20 \mathrm{~km}$ northeast of Al-Ansab 1. The site lies in the eastern escarpments of the Jordanian Rift at an elevation of $610 \mathrm{~m}$ above sea level. It is located on a local ridge at the wadi base, which is composed of Pleistocene sediments. The sediment mound was preserved due to a limestone ridge of the Umm Rijam Chert Formation, shielding the material from erosion by the discharging wadi. Today, the promontory of Al-Ansab 1 is elevated about $20 \mathrm{~m}$ above the current wadi floor. Besides the Early Ahmarian site (Al-Ansab 1), materials from earlier stages like the Initial Upper Palaeolithic (Al-Ansab 2) and the Emiran (Al-Ansab 4) could also be documented. AlAnsab 1 was excavated in the context of the CRC 806 from 2008 to 2020. It provides two archaeological strata, which are separated by a sterile layer of about $145 \mathrm{~cm}$. To date, only the upper layer has been excavated extensively, leaving the lower stratum for later projects. 
Excavations of the top layer yielded a large amount of lithic material. The preservation of bone material was poor, largely providing fragments. However, the presence of Gazella sp. could be determined by the presence of molars (Parow-Souchon, 2020). Intrasite distribution patterns show repeated clusters of silices, bone fragments and charcoal scatters. These are characteristic of repeated short-term occupations by relatively small bands of hunter-gatherers exploiting the local silex raw materials, burning wood and leaving traces of several fireplaces (Richter et al., 2020). The general abundance of lithic artefacts, the completeness of the chaîne opératoire and the relatively high level of assemblage diversity speak for both a great variability of tasks executed on site and a high settlement intensity (Parow-Souchon, 2020). Given the assumption of high residential mobility of comparably small bands of hunter-gatherers, the site probably represents the palimpsest of several occupations (Schoenenberg \& Sauer, in prep.). On a larger scale, the presence of marine molluscs in the assemblage excavated et al.-Ansab 1 points towards connections to either the Red Sea to the Southwest or the Mediterranean to the West (Richter et al., 2020). In any case, the site is embedded in a mobility pattern that bridges variable landscapes and environments.

Large flint outcrops in the immediate vicinity of Al-Ansab 1 were intensively used at the time of occupation. The tectonic history of the region has generated a landscape where silex raw materials appear almost ubiquitous (Parow-Souchon \& Purschwitz, 2020). Silex could be obtained at many places during the annual round by the Early Ahmarian hunter-gatherers (Binford, 1979; Olszewski \& Schurmans, 2007; ParowSouchon \& Purschwitz, 2020). In our understanding, this did not necessitate raw material-oriented site placement in the region. Furthermore, a spring is situated only a few hundred metres to the Southeast. It is the result of several major fault zones in the geology around the lower Wadi Sabra (Parow-Souchon, 2020). In general, these faults trigger the formation of springs. Today, the spring et al.-Ansab is active, even under the much dryer Holocene conditions. It is fed by local aquifers of the Transjordanian highlands and supplies water to the local environment, which shows by the dense vegetation along the sides of the small tributary wadi. As groundwater levels have dropped substantially since the beginning of the intense use of this resource for farming in Jordan, the discharge volume of this spring probably decreased (Goode et al., 2013). This was confirmed by local Beduin farmers, too.

The current, local wadi morphology is the result of relatively recent erosive activities. At the end of the Pleistocene, intense discharge events eroded the Pleistocene wadi fill. Sedimentological analysis shows that at the time of occupation, the wadi was filled to the level of the site with material testifying to sheet flow events leading to a positive sediment balance (Bertrams, 2013; Bertrams et al., 2014). The massive Pleistocene sediment would have increased water retention capacities around the site (Parow-Souchon, 2020).

\section{Gazelle, Deer and Their Environment}

The two main species of prey for the hunter-gatherers of the Early Ahmarian were gazelle and deer (Fig. 3). These two species can be detected in sites throughout the Levant. Within the trio of fats, proteins and carbohydrates 
(Cachel, 1997), gazelles and deer have been one of the primary sources of animal proteins. At Üçağızlı, a specialisation in the spectrum of hunted prey during the Early Upper Palaeolithic could be observed (Stiner, 2009). However, the repeated presence of ostrich eggshells at Early Ahmarian sites exemplifies the bandwidth of protein sources at the time (Gilead, 1983, 1984). Also, the occurrence of marine seashells at Early Ahmarian sites suggests connections to coastal environments and the related terrestrial and marine resources (Coinman \& Henry, 1995; Gilead \& Bar-Yosef, 1993; Kerry \& Henry, 2003; Kuhn et al., 2009; Pastoors et al., 2008; Schyle et al., 2015). For Ksâr 'Akil and Üçağızlı, an increase in shellfish exploitation during the Early Upper Palaeolithic could be observed (Bosch et al. 2018). Dama sp. shows a spatial focus on the Mediterranean biome. In contrast, Gazella sp. seems to be more widely spread with occurrences in Ahmarian sites in the Transjordan escarpments and the south of the Sinai Peninsula. At Manot Cave, but also in other Early Ahmarian sites, deer (more specifically at Manot Cave: Dama mesopotamica) had been hunted alongside mountain gazelles (Shea et al., 2019; Yeshurun et al., 2019). Yeshurun et al. interpret this as an indicator for the mosaic of both forested and

Fig. 3 Map of Gazella sp. and Dama sp. distribution in sites of the Early Ahmarian; triangles represent sites with the exclusive presence of gazelle in the assemblages, dots represent sites which only included deer and squares represent sites which included

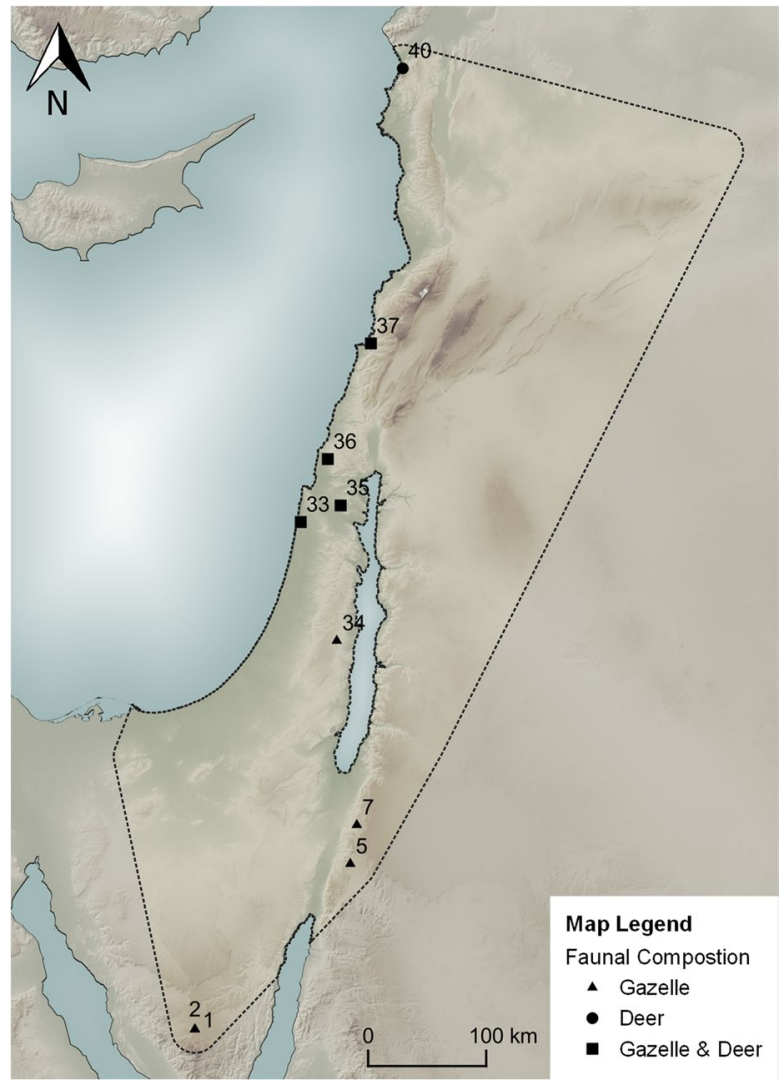


shrub-covered areas around Manot Cave. While deer is associated with forest elements, mountain gazelles roam open-landscape components and occasionally browse in forests, too (Martin, 2000; Rabinovich, 2003).

With Gazella sp., the environmental correlates vary throughout the study area. Two major gazelle species were exploited in the Upper Palaeolithic of the Levant. These are the mountain gazelle, Gazella gazella, which was distributed in the Mediterranean biome and Gazella subgutturosa, the goitered gazelle, which was present in the eastern and southern sections of the Levant (Rabinovich, 2003). Today, both species prefer somewhat different habitats within the study area (Martin, 2000). Gazella gazella today inhabits woodland and steppe biomes with relatively moderate maximum summer temperatures (c. $35{ }^{\circ} \mathrm{C}$ ) and higher precipitation rates $(500-700 \mathrm{~mm})$.

In contrast, the heavier goitered gazelle (Martin, 2000) is known today in steppic and desertic areas with summer temperatures up to $45{ }^{\circ} \mathrm{C}$ and lower annual rainfall sums (100-200 mm). Artemisia spp. steppe environments are a dominant habitat for the goitered gazelle (Khosravi et al., 2016). Between both species, Gazella subgutturosa shows a more expressed migratory behaviour with comparably large home ranges, whereas Gazella gazella seems to circulate relatively small areas (Martin, 2000). However, in all case studies, modern land use, human settlement and enclosure size may influence spatial behaviour. Under varying climatic and environmental conditions, Gazella subgutturosa can show different levels of mobility (Martin, 2000). For the Epipalaeolithic settlement at Kharaneh IV in the Azraq basin, gazelles were circulating in the highlands and did not retreat to lower altitudes during winter (Henton et al., 2018).

Many Early Ahmarian sites in the Levant do not provide information on hunted fauna. Among other factors, excavation techniques and preservation have truncated the dataset. In total, deer and gazelle could be determined for ten sites in the study area (Fig. 3). These sites spread over the Mediterranean, Saharo-Arabian and Irano-Turanian biomes and show different faunal compositions. One location shows the sole exploitation of deer (Kuhn et al., 2009), four show the combined hunting of both deer and gazelles (Hooijer, 1961; Rabinovich, 2003; Yeshurun et al., 2019) and five sites show the exclusive exploitation of gazelles (Lieberman, 1995; Parow-Souchon, 2020; Phillips, 1988; Rabinovich, 2003; Richter et al., 2020) (Table 1). The other sites used in this publication (see also Geospatial Data section) do not provide any data on faunal composition.

Generally, the prevailing environment is dominated by vegetational societies associated with the respective biomes. In the Mediterranean biome, aspects of woodland vegetation speak for the comparably humid conditions which promote the growth of trees such as oak (Quercus) or almond (Amygdalus) (Caracuta et al., 2020; Litt et al., 2012; Richter et al., 2020). In contrast, the Saharo-Arabian and Irano-Turanian biomes provide traces of Amaranthi and Artemisia as representatives of low annual precipitation environments (Litt et al., 2012; Richter et al., 2020; Zohary, 1962). 


\begin{tabular}{llll}
\cline { 2 - 4 } $\begin{array}{l}\text { Table } 1 \text { Table of major prey } \\
\text { species observed in faunal } \\
\text { assemblages of Early Ahmarian }\end{array}$ & ID & Site name & Faunal composition \\
\cline { 2 - 4 } sites in the Levant & 1 & Abu Noshra I & Gazelle \\
& 2 & Abu Noshra II & Gazelle \\
& 5 & Tor Hamar (J431) & Gazelle \\
& 7 & Al-Ansab 1 & Gazelle \\
& 33 & Kebara IV-III & Gazelle \& deer \\
& 34 & Erq el-Ahmar E-F & Gazelle \\
& 35 & Qafzeh & Gazelle \& deer \\
& 36 & Manot cave & Gazelle \& deer \\
& 37 & Ksar Akil VI-XIX/XX & Gazelle \& deer \\
& 40 & Üçağılı & Deer \\
\hline
\end{tabular}

\section{Geospatial Data}

The study analyses a dataset of 40 Early Ahmarian sites covering the Sinai Peninsula (Gilead, 1983, 1984; Phillips, 1988, 1991), the Negev desert (Bar-Yosef \& Belfer, 1977; Gilead \& Bar-Yosef, 1993; Goring-Morris, 1995; Goring-Morris \& Belfer-Cohen, 2018; Goring-Morris \& Davidzon, 2006), the Dead Sea Transform, Transjordan (Clark et al., 2017; Coinman \& Henry, 1995; Kerry \& Henry, 2003; Richter et al., 2020; Schuldenrein \& Clark, 2001), Israel (Bar-Yosef \& Belfer-Cohen, 2004; Belfer-Cohen \& Goring-Morris, 2003, 2012; Caracuta et al., 2020; Yeshurun et al., 2019; Ziffer, 1978), Lebanon (Bergman, 1988; Bergman et al., 2017; Douka et al., 2013), Syria (Pastoors et al., 2008; Ploux \& Soriano, 2003) and Turkey (Kuhn, 2004; Kuhn et al., 2009). It was compiled in the context of the CRC 806 and the GEOPAL project at the University of Cologne. All coordinates were taken from the literature and checked for accuracy by surveying the literature for maps and coordinates since viewshed analysis is vulnerable to locational imprecision. In this analysis, only sites which were attributed unequivocally to the Early Ahmarian by the authors were included. Sites like Mughr El-Hamamah (Belmaker et al., 2014; Shea et al., 2019), Raqefet (Lengyel, 2007) or Tor Fawaz (Kerry \& Henry, 2003) were not included due to the atypical characteristics of the assemblages.

The topographic basis for analysis is the ASTER 3 digital elevation model (NASA et al., 2019). It is issued in $1^{\circ} \times 1^{\circ}$ tiles with $30-\mathrm{m}$ postings. The ASTER 3 root mean square error is $8.52 \mathrm{~m}$ and the mean error is $-1.2 \mathrm{~m}$ (Besch et al., 2016). For purposes of removing outliers and smoothing the surface, the elevation model was filtered with a Gauss filter (1 Stdev., search radius 10 cells, circular neighbourhood, SAGA Geostatistics Software). The smoothing also provides a more generalised landscape model removing topographic variability insignificant on a longer temporal scale.

The study area was defined by the convex hull enclosing the archaeological sites of the Early Ahmarian in the Near East. The convex hull was extended by a $20-\mathrm{km}$ buffer to accommodate for potential catchment ranges of the marginal sites. This 
area, which covers c. $18,700 \mathrm{~km}^{2}$, is considered to be the context area (Richter et al., 2012) of the Early Ahmarian in the Levant.

\section{Processing Visual Neighbourhood with Higuchi Viewsheds}

A Higuchi viewshed approach is used to evaluate the visual properties of the Early Ahmarian sites (Higuchi, 1985; Wheatley \& Gillings, 1999). The focus lies on gazelles as one of the important prey species. The Higuchi approach classifies visibility and visual experience based on the physical limitations to human perception. Within certain thresholds of visual angles, the human eye can discern between object presence and absence or resolve an object's shape. Archaeologically, this is important for evaluating the visual suitability of the landscape for hunting. Depending on prey size, different locations provide different suitability for detecting (here: visual perception of object presence) and recognising (here: visual perception of characteristic shapes to classify object) objects of interest.

Visual acuity limits of the human eye are by no means absolute, but change with age or are restricted by other, individual factors. In this study, we use 1 ' acuity to distinguish between two-point targets (object detection) and 5' acuity for determining object shape (Healey \& Sawant, 2012). Based on these acuity angles, two distance thresholds of visibility can be calculated for objects of a given size. For gazelles, we employ an animal height of $110 \mathrm{~cm}$ (head height) and length of $170 \mathrm{~cm}$ resulting in a diagonal animal size of $202 \mathrm{~cm}$ according to the Pythagorean theorem. These values are at the top of the observed range of gazelle body sizes, while Gazella dorcas represents one of the smallest gazelle species with a body length of $\mathrm{c} .110 \mathrm{~cm}$ (Martin, 2000; Taha et al., 2018; Wronski et al., 2010). However, body size varies between different species of gazelles. The diagonal animal size is used to calculate the maximum distance of visibility using the trigonometric formula:

$$
d=0.5 \mathrm{~s} / \tan (0.5 \theta)
$$

where $d$ is the maximum visual distance, $s$ is the diagonal maximum extent of the animal and $\theta$ is the visual angle.

Consequently, detection is limited to a maximum distance of $7000 \mathrm{~m}$ (6944 m) and recognition is limited to a maximum distance of $\sim 1400 \mathrm{~m}(1388 \mathrm{~m})$. These two boundaries form the thresholds for generating the total Higuchi viewsheds.

General geostatistical processing was done using Quantum GIS 3.10.7 (QGIS 2020). The total viewsheds (TVS) were processed using the Quantum GIS plugin "visibility analysis" (Cuckovic, 2016). Two total viewsheds were generated: one with a maximum viewing distance of $1400 \mathrm{~m}$ and one for $7000 \mathrm{~m}$ to accommodate for the different levels of visual acuity. Since processing a "true" total viewshed (on observer point on every raster cell) was not possible due to computational limitations, the points were spaced at intervals of $250 \mathrm{~m}$. Observer height was set to $1.75 \mathrm{~m}$ (Piontek \& Vancata, 2012) and target height to $1.1 \mathrm{~m}$. To generate the visual neighbourhoods, the TVS values are sampled to the catchments of the individual archaeological sites. 


\section{Site Catchments}

Site catchments based on landscape accessibility form the basis for determining the general visual properties of a site location. Site catchments were calculated using a hiking function (van Wagtendonk \& Benedict, 1980; Watts et al., 2003) at a base speed of $1.3 \mathrm{~m} / \mathrm{s}$. The underlying digital elevation model for accessibility modelling was a resampled $250 \mathrm{~m}$ version of the ASTER 3 elevation model (NASA et al., 2019) of the region. We resampled the elevation model to accommodate for geomorphological change and inaccuracies since the time of occupation. The catchments were modelled in 1-h increments to a maximum walking time of $4 \mathrm{~h}$ and subdivided into four isochrone rings (annuli of $1 \mathrm{~h}$ ), each. Modelling was done using ArcGIS 10.1. Visual properties of the landscape within the 1-h to 4-h isochrone rings were sampled (Fig. 4). The 1-h isochrone was concerned with the near-field area of the respective site.

A sampling of the site catchments was conducted using the QGIS function "zonal histogram" and summary statistics for the individual site catchments were generated using the GRASS GIS function v.rast.stats. Statistical analysis was conducted in R (version $\times 64$ 4.0.3).

Fig. 4 Map of the catchments modelled for use in this paper; all catchments were modelled up to a cost distance of $4 \mathrm{~h}$

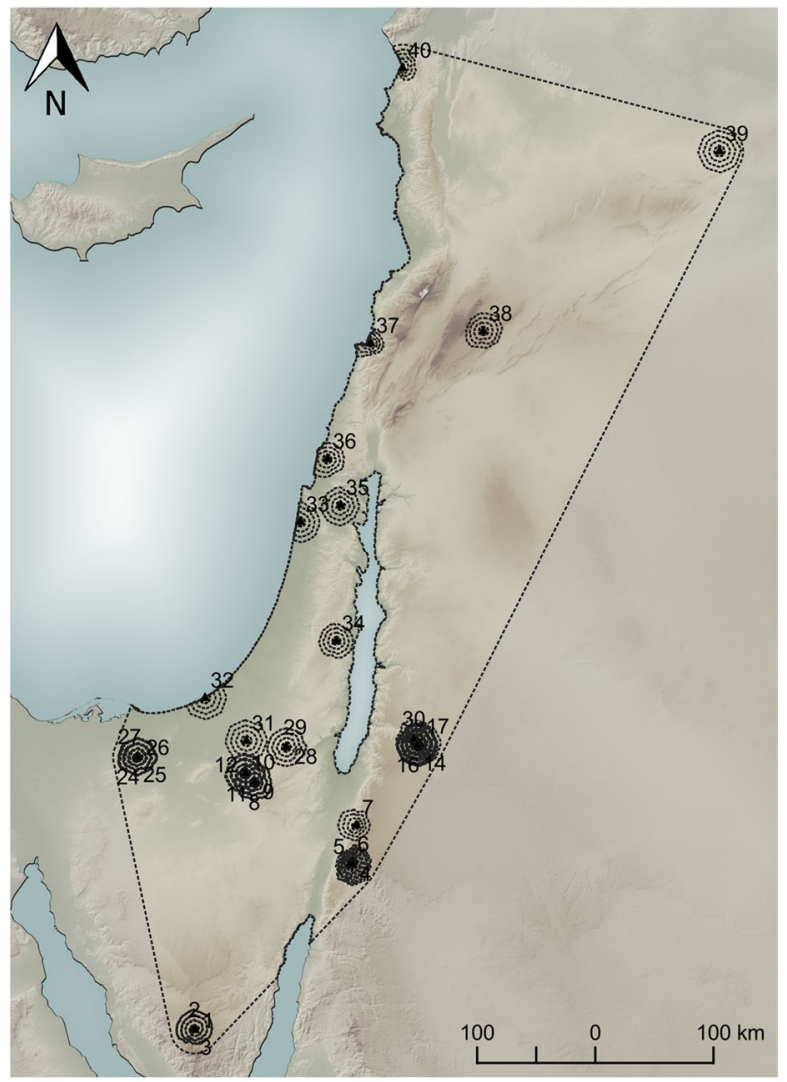




\section{Results}

General visibility conditions in the study area for an acuity of $5^{\prime}$ (max. distance $1400 \mathrm{~m}$; at object diameter $2.02 \mathrm{~m}$; object height: $1.1 \mathrm{~m}$; observer height: $1.75 \mathrm{~m}$ ) range from 0 to 98 (overlapping views), with a mean of 21.1 (Figs. 5a and 6a). Processing at a point spacing of $250 \mathrm{~m}$ resulted in a $0.1 \%$ frequency of zero overlaps (invisibility) throughout the study area which is considered insignificant to the analysis. The greatest frequency in overlap shows at a value of 13 with $3.3 \%$ of the total dataset.

The general visibility conditions in the study area for an acuity of 1' (max. distance $7000 \mathrm{~m}$; at object diameter $2.02 \mathrm{~m}$; object height: $1.1 \mathrm{~m}$; observer height: $1.75 \mathrm{~m}$ ) range from 0 to 1707 (overlapping views), with a mean of 158 (Figs. 5b and $6 \mathrm{~b}$ ). Processing at a point spacing of $250 \mathrm{~m}$ resulted in a less than $0.1 \%$ frequency of zero overlaps (invisibility) throughout the study area which is considered insignificant to the analysis. The greatest frequency in overlap occurs at a value of 7 with $0.9 \%$ of the total dataset.

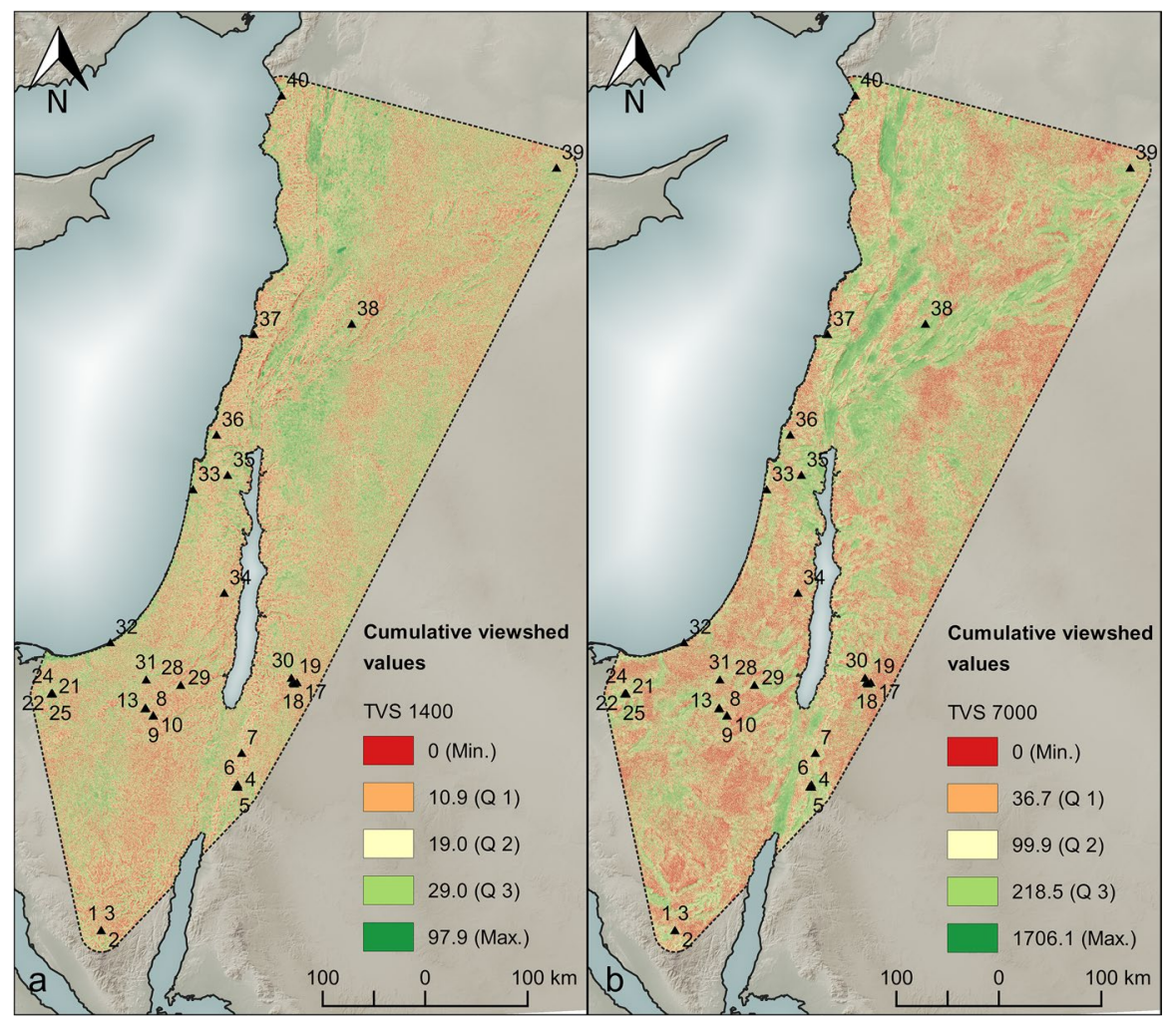

Fig. 5 Higuchi viewshed TVS1400 (a) and Higuchi viewshed TVS7000 (b) maps and the distribution of cumulative viewshed values; red reflects areas of low visibility while green areas reflect areas of high visibility; the color breaks were set by the quantiles of the value 

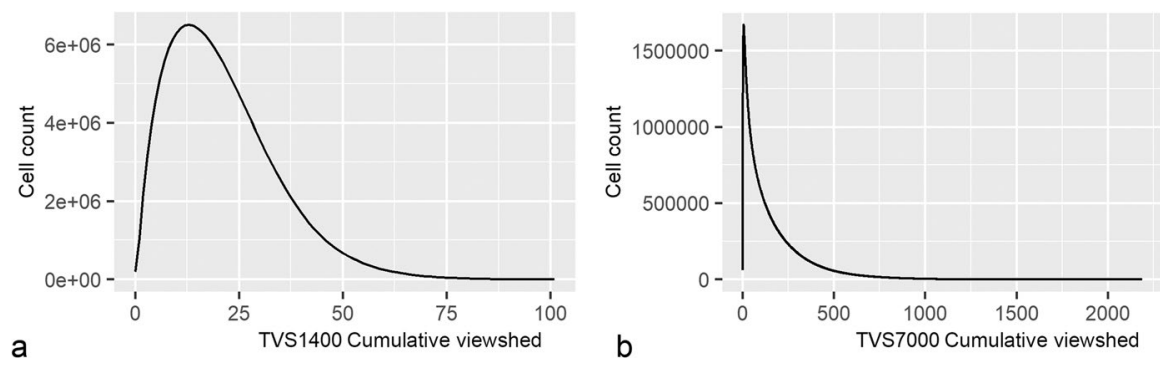

Fig. 6 Higuchi viewshed TVS unique value counts for the entire study area for the maximum viewing distance of $1400 \mathrm{~m} \mathrm{(a)}$ and $7000 \mathrm{~m}(\mathbf{b})$

Site catchments were sampled throughout the individual 1-h annuli. Analysis was grouped by the presence of different prey species in the faunal assemblages of the individual sites. The observed values in the catchments of the sites in the study area range from median values of 16.2 to 31.3 (TVS $_{1400}$ ) and 87.6 to 356.4 $\left(\mathrm{TVS}_{7000}\right)$ for the 1-h catchment. With increasing distance to the sites, the general mean TVS 1400 values drop to maximum values of c. 25 . All individual values are represented in Online Resource 2.

The TVS summary statistics for the Early Ahmarian sites in the study area show a grouping of sites with low local visibility (max. viewshed: $1400 \mathrm{~m}$ ), in which solely gazelle was documented (Fig. 7). The mean $\mathrm{TVS}_{1400}$ values range between $\sim 17$ and $\sim 19$. Four out of these five sites are placed outside the Mediterranean Biome as it had been modelled for the MIS 3 conditions $\left(-3^{\circ}\right.$ annual mean temperature, $-15 \%$ annual precipitation sum) by Miebach et al. (2019).

This is contrasted by a group of sites in which both deer and gazelle were documented. The mean TVS values stretch over a wider range $\left(\mathrm{TVS}_{1400}: \sim 16\right.$ to $\sim 28$ ). Finally, at Üçağızlı, very high levels of close-range visibility can be detected $\left(\mathrm{TVS}_{1400}\right.$ : 32). Here, only Dama mesopotamica has been detected as large prey in the faunal assemblage. This situation dissolves slightly with increasing distance to the campsite (Fig. 8).

Furthermore, a gap between a group of sites with low $\mathrm{TVS}_{1400}$ values and a group with higher TVS $_{1400}$ values can be observed (Fig. 7). This gap dissolves with increasing distance from the centre of the respective isochrone. Plotted with the associated biome attribution, the sites with no information on faunal composition in the low $\mathrm{TVS}_{1400}$ value cluster are exclusively associated with the open-vegetation environments of the Saharo-Arabian and Irano-Turanian Biomes (Fig. 9).

With long-range visibility (max viewshed: $7000 \mathrm{~m}$ ), the situation is less pronounced (Fig. 8). Here, grouping is little throughout all isochrones. Ninety-five percent of all sites are located in the lower half of the $\mathrm{TVS}_{7000}$ range. Sites in which gazelle is the only large ungulate fauna (Al-Ansab 1, Abu Noshra I \& II, Erq el-Ahmar, Tor Hamar,) stretch over a wider range and sites of combined hunting prey seem to cluster slightly stronger. While for the $\mathrm{TVS}_{1400}$ values, a strong change in conditions as well as a gap between two major groups of visibility 


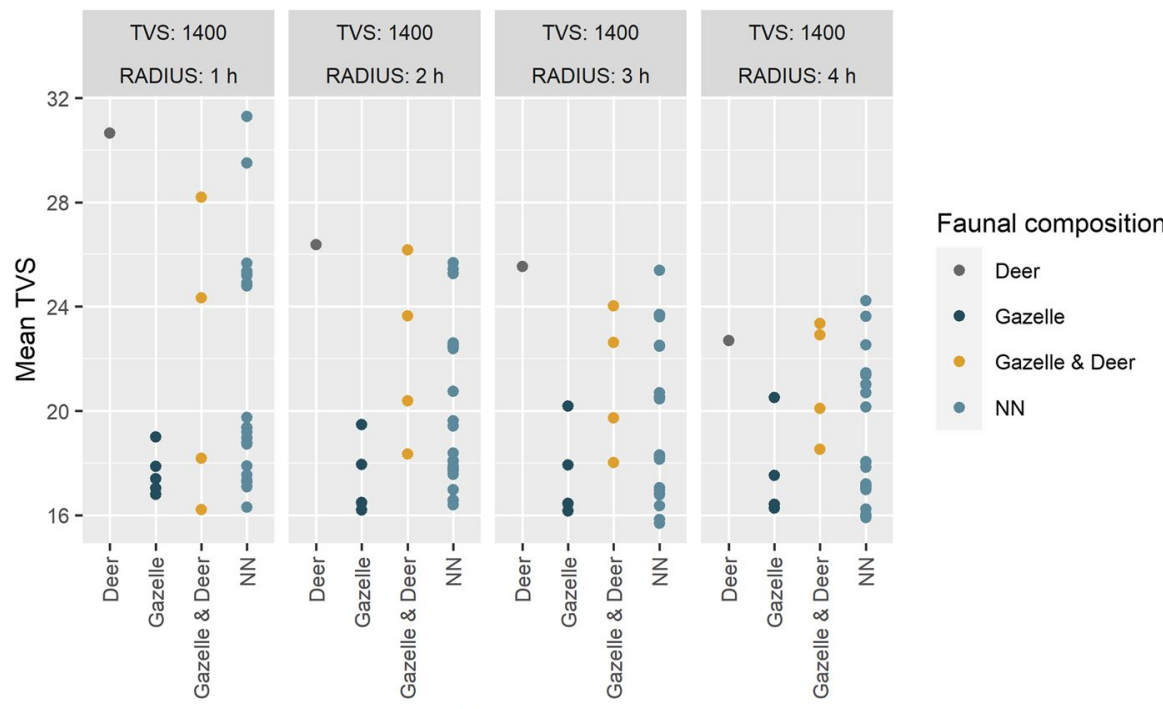

Faunal Composition

Fig. 7 Mean Higuchi viewsheds TVS $_{1400}$ values for sites of different faunal composition filtered by the respective isochrone annuli; grey dots represent sites in which only deer could be observed, dark blue dots represent sites in which only gazelle could be observed, yellow dots represent sites with both gazelle and deer in the assemblage and light blue dots represent sites without faunal data on deer and gazelle; diagrams are sorted by catchment isochrone

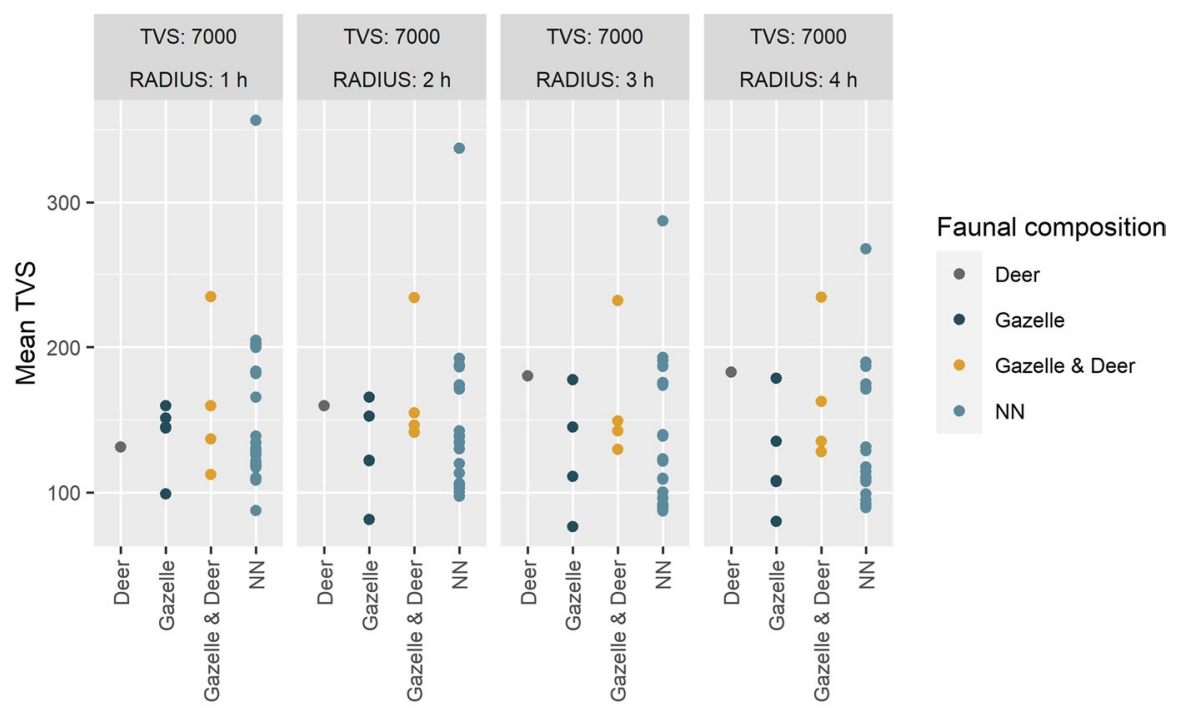

Faunal Composition

Fig. 8 Mean Higuchi viewshed $\mathrm{TVS}_{7000}$ values for sites of different faunal composition filtered by the respective isochrone annuli; grey dots represent sites in which only deer could be observed, dark blue dots represent sites in which only gazelle could be observed, yellow dots represent sites with both gazelle and deer in the assemblage and light blue dots represent sites without faunal data on deer and gazelle; catchments are sorted by catchment isochrone 


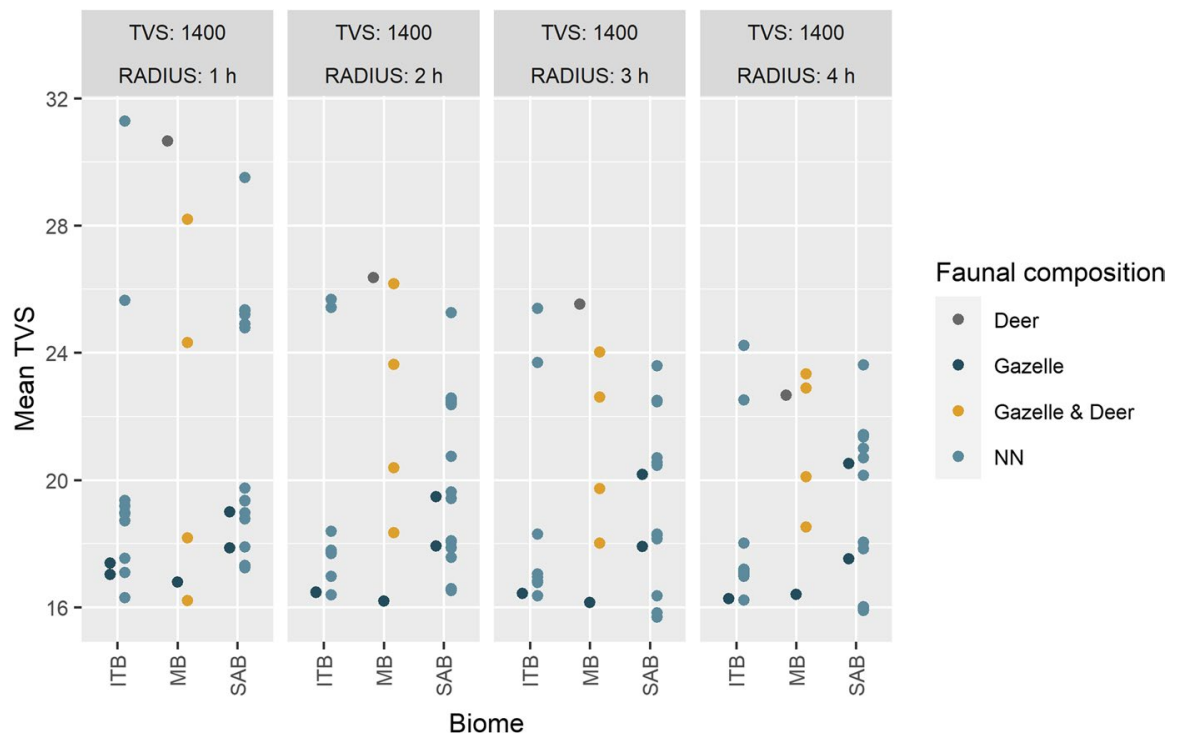

Fig. 9 Higuchi viewshed TVS1400 values sorted by faunal composition and biome attribution; grey dots represent sites in which only deer could be observed, dark blue dots represent sites in which only gazelle could be observed, yellow dots represent sites with both gazelle and deer in the assemblage and light blue dots represent sites without faunal data on deer and gazelle; catchments are sorted by catchment isochrone

could be observed throughout the different isochrones; this signal is less clear for the $\mathrm{TVS}_{7000}$ values throughout the different annuli.

The compositions of the different groups were tested for independence using the Mann-Whitney $U$ test (Mann \& Whitney, 1947). No distribution showed significant dependence on any other distribution (Table 2). The general distributions were independent from each other (Table 3).

When the sites of different ungulate prey compositions are plotted on top of the biome probability model as provided by Miebach et al. (2019), it becomes apparent that the different compositions strongly correlate with the different biomes. Particularly, sites showing hunting of deer or deer and gazelle are placed in the Mediterranean biome, while gazelle-only sites are situated in the Saharo-Arabian and Irano-Turanian biome. This also coincides with a clear division of prey composition and Early Ahmarian subgroup attribution (Figs. 10 and 11).

For the site of Al-Ansab, the $\mathrm{TVS}_{1400}$ values range from an average of 17.9 (1-h isochrone) to 17.5 (4-h isochrone). The maximum lies at a value of 79 overlaps. The $\mathrm{TVS}_{7000}$ values range from 151.4 (1-h isochrone) to 135.3 (4-h isochrone). The maximum lies at a value of 1504 overlaps.

\section{Discussion}

Before discussing the results of the TVS analysis, it has to be stated that the data presented here reflects results adhering to the parameters of the model which simplifies decision-making processes of the past. Other factors of the human agency 
Table $2 p$-values of the Mann-Whitney $U$ test for independence of means (1-h catchment); all distributions show statistical independence from each other

\begin{tabular}{|c|c|c|c|}
\hline TVS 1400 & Gazelle deer $(n=4)$ & Deer $(n=1)$ & $\mathrm{NN}(n=30)$ \\
\hline Gazelle $(n=5)$ & $\begin{array}{l}p<0.01 \\
W=1.2423 \mathrm{e}+10\end{array}$ & $\begin{array}{l}p<0.01 \\
W=516909428\end{array}$ & $\begin{array}{l}p<0.01 \\
W=1.1286 \mathrm{e}+11\end{array}$ \\
\hline Gazelle deer $(n=4)$ & & $\begin{array}{l}p<0.01 \\
W=544694570\end{array}$ & $\begin{array}{l}p<0.01 \\
W=1.1504 \mathrm{e}+11\end{array}$ \\
\hline $\operatorname{Deer}(n=1)$ & & & $\begin{array}{l}p<0.01 \\
W=8381829652\end{array}$ \\
\hline TVS 7000 & Gazelle deer $(n=4)$ & $\operatorname{Deer}(\mathrm{n}=1)$ & $\mathrm{NN}(n=30)$ \\
\hline Gazelle $(n=5)$ & $\begin{array}{l}p<0.01 \\
W=1.4243 \mathrm{e}+10\end{array}$ & $\begin{array}{l}p<0.01 \\
W=802964196\end{array}$ & $\begin{array}{l}p<0.01 \\
W=1.2768 \mathrm{e}+11\end{array}$ \\
\hline Gazelle deer $(n=4)$ & & $\begin{array}{l}p=0.046 \\
W=754632974\end{array}$ & $\begin{array}{l}p<0.01 \\
W=1.1462 \mathrm{e}+11\end{array}$ \\
\hline Deer $(n=1)$ & & & $\begin{array}{l}p=0.016 \\
W=6614439800\end{array}$ \\
\hline
\end{tabular}

may have played a fundamental role in the formation of the archaeological record. Among these could be the exploitation of lithic or other organic raw materials and cultural constraints. For many sites of the Early Ahmarian, a tethering to locations of water availability could be observed in strongly varying environmental contexts (Clark et al., 2017; Lieberman, 1995; Phillips, 1988, 1991; Schuldenrein \& Clark, 2001). This indicates the importance of ecological variables to the placement of sites in the Early Ahmarian context. In opposition to the Middle Palaeolithic, we can observe a focus of the prey spectrum on gazelle-sized ungulates during the Early

Table $3 p$-values of the Kolmogorov-Smirnov test for independence distributions (1-h catchment); all distributions show statistical independence from each other.

\begin{tabular}{llll}
\hline TVS 1400 & Gazelle deer $(n=4)$ & Deer $(n=1)$ & NN $(n=30)$ \\
\hline Gazelle $(n=5)$ & $p<0.01$ & $p<0.01$ & $p<0.01$ \\
Gazelle deer $(n=4)$ & $D=0.13993$ & 0.41989 & $D=0.10852$ \\
& & $p<0.01$ & $p<0.01$ \\
Deer $(n=1)$ & $D=0.28269$ & $D=0.044054$ \\
& & & $p<0.01$ \\
TVS 7000 & & & $D=0.32504$ \\
Gazelle $(n=5)$ & Gazelle deer $(n=4)$ & Deer $(n=1)$ & NN $(n=30)$ \\
Gazelle deer $(n=4)$ & $p<0.01$ & $p<0.01$ & $p<0.01$ \\
& $D=0.099384$ & $D=0.1546$ & $D=0.07676$ \\
Deer $(n=1)$ & $p=0.046$ & $p<0.01$ \\
& & $D=0.19778$ & $D=0.023765$ \\
& & & $p<0.01$ \\
& & & $D=0.17487$ \\
\hline
\end{tabular}




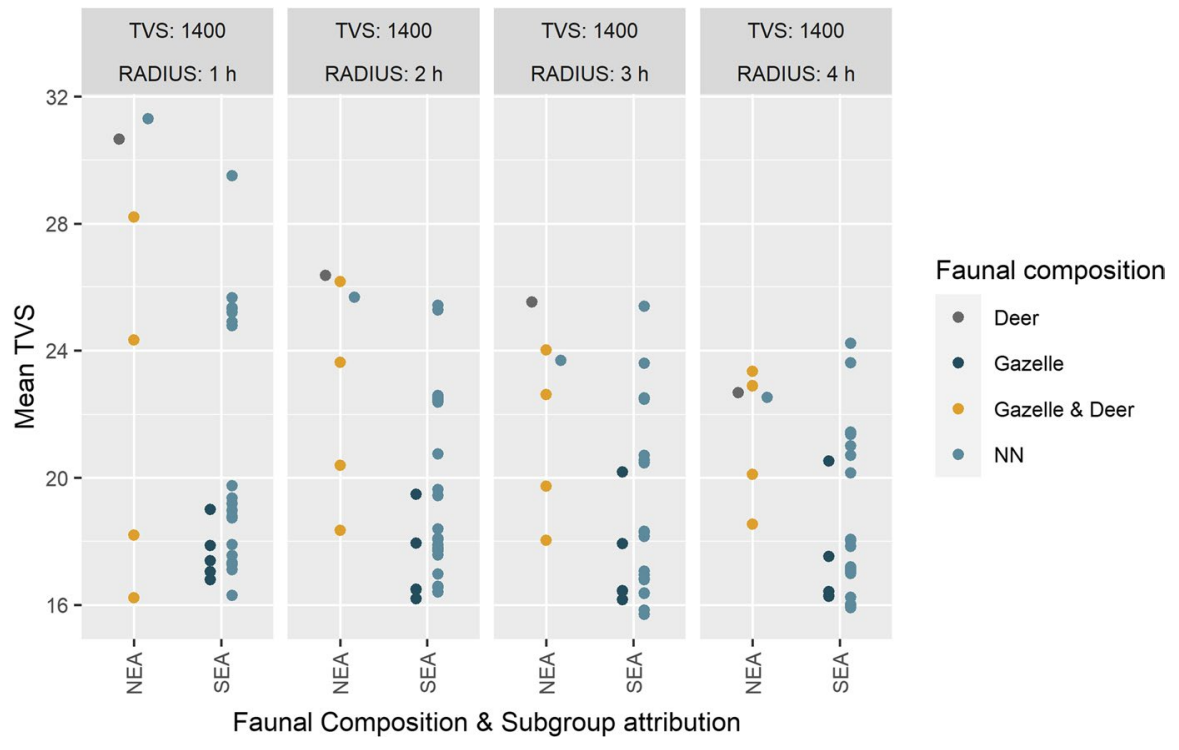

Fig. 10 Faunal composition, Early Ahmarian subgroup attribution and Higuchi viewshed TVS1400 values; grey dots represent sites in which only deer could be observed, dark blue dots represent sites in which only gazelle could be observed, yellow dots represent sites with both gazelle and deer in the assemblage and light blue dots represent sites without faunal data on deer and gazelle; catchments are sorted by catchment isochrone

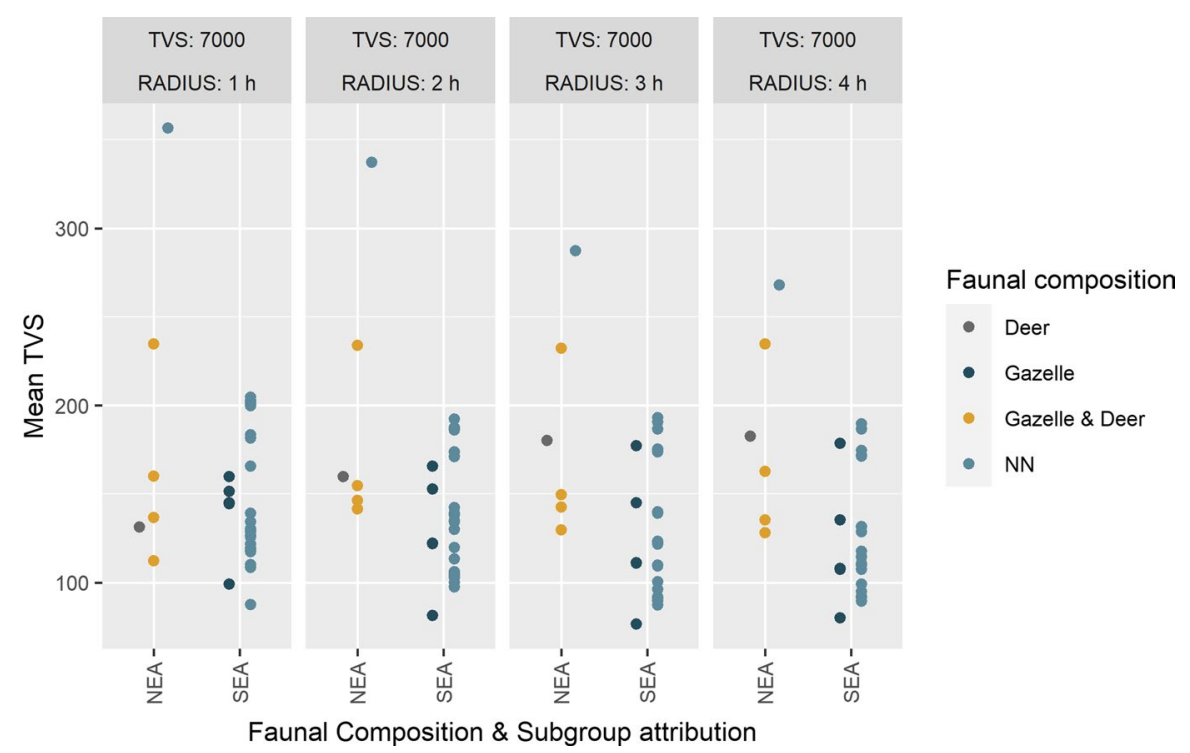

Fig. 11 Faunal composition, Early Ahmarian subgroup attribution and Higuchi viewshed TVS7000 values; grey dots represent sites in which only deer could be observed, dark blue dots represent sites in which only gazelle could be observed, yellow dots represent sites with both gazelle and deer in the assemblage and light blue dots represent sites without faunal data on deer and gazelle; catchments are sorted by catchment isochrone 
Upper Palaeolithic (Rabinovich, 2003, 2017; Stiner, 2009). However, the dietary spectrum also contains protein-resources such as shellfish in coastal areas (Bosch et al., 2018) and ostrich eggs (Gilead, 1983, 1984). The humid conditions around many of the Early Ahmarian sites also provided a set of vegetal resources.

This analysis only includes sites unequivocally attributed to the Early Ahmarian in the literature. As stressed on different occasions (Sauer \& Riede, 2018; Shea, 2014; Shea et al., 2019), named stone tool industries obscure variability by forcing the application of classificatory systems. The notion of ethnicity is not intended by the use of the term "Early Ahmarian". The Early Ahmarian is solely understood as a unit of common technotypological attributes within the area of the Levant and adjacent regions.

\section{Visual Conditions Around the Site of Al-Ansab 1}

The site of Al-Ansab 1 shows a low visibility on both 1' and 5' visual acuity. This represents a visual focus on the immediate vicinity around the site. Throughout all annuli, the visual conditions suggest low visual permeability of the landscape. In general, the landscape accessible from the site did not provide conditions, which permitted a good overview over events taking place in the far field, even though the surrounding landscape would have provided such locations (Fig. 12). The choice of location could be explained by both the spatial behaviour of the goitered gazelle (Gazella subgutturosa) and the local environmental conditions at the time of occupation. Water is provided by a local spring and the humidity of seasonal rainfalls is retained in the massive sediment package. These conditions permitted the yearround growth of plants, making the location particularly attractive for both Pleistocene hunter-gatherers and their prey. Most likely, Gazella subgutturosa had been hunted at or near the site since this species could be observed at other sites in the region, too (Rabinovich, 2003). The deeply incised local morphology of the Wadi Sabra acts as a channel of movement between the Transjordan highlands and the Wadi Araba. The relatively small extent of the Wadi Sabra of roughly $20 \mathrm{~km}^{2}$ may not have sufficed to support a gazelle population necessitating their migratory behaviour, given documented gazelle range sizes (Martin, 2000). We consider the site of Al-Ansab 1 to be a location at which Early Ahmarian hunters awaited the presence of their intended prey. The locally humid conditions acted as a magnet pulling-in gazelles and making the site a location of high prey predictability. This necessitated a close-range visual focus while far-field observation was not relevant. The attractivity of the location was further increased by the availability of high-quality lithic raw material in close vicinity to the site (Parow-Souchon, 2020). It was used intensively for tool production during the occupation of the site.

\section{Near-Field and Far-Field Visibility Around Sites in the Early Ahmarian}

The sites of the Early Ahmarian are situated in different environmental settings throughout the Levant. Coastal sites are placed in the Mediterranean Biome, which provides a mosaic of forested and open-landscape elements. The other sites are placed in the Saharo-Arabian and Irano-Turanian biomes (Richter et al., 2020). 


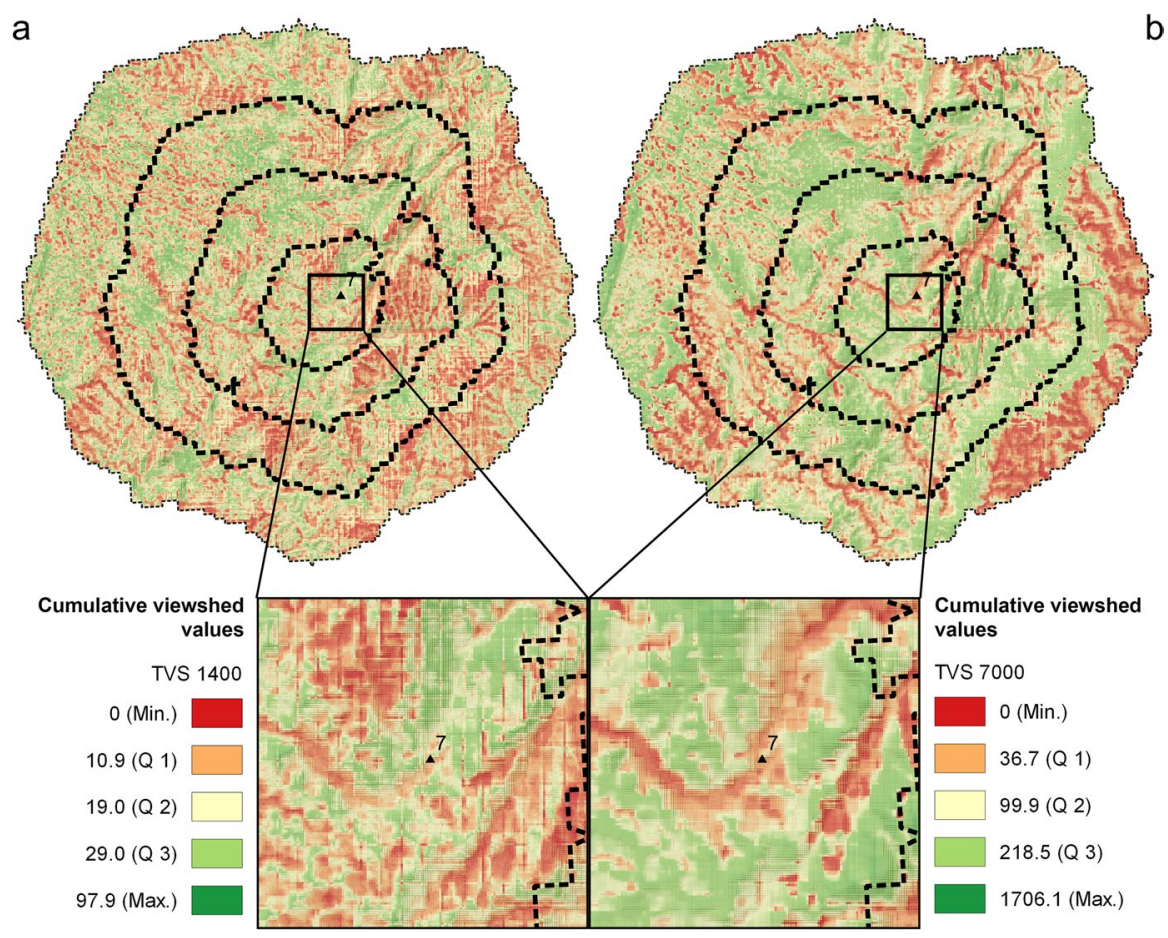

Fig. 12 Visibility conditions in the one to 4-h catchments of the site of Al-Ansab 1; a shows the closerange visibility $\left(\mathrm{TVS}_{1400}\right)$ while b shows the far-field visibility $\left(\mathrm{TVS}_{7000}\right)$; at the bottom, the positioning of the site within the Wadi Sabra is shown

There, the Artemisia steppe dominates the landscape due to the more arid conditions (Miebach et al., 2019; Richter et al., 2020). These conditions prevail even under generally more humid conditions as they are assumed for the mid-MIS 3 timeframe of the Early Ahmarian (Gladfelter, 1997; Miebach et al., 2019).

The faunal assemblages of Early Ahmarian archaeological sites—even if they are small in number-show a pattern of primarily hunted prey. In the Mediterranean biome, both Dama mesopotamica and Gazella gazella are hunted. This seems to fit the environmental preferences of both species, which roam the forested patches of the biome (Dama mesopotamica) or alternate between steppic and forested areas (Gazella gazella). Sites in the dryer southern and eastern sections of the Early Ahmarian territory show the exploitation of Gazella subgutturosa, which today is associated with steppic and dry environments as well. The goitered gazelle (Gazella subgutturosa) shows a greater tendency for large-scale mobility than the smaller mountain gazelle. Artemisia steppe vegetation, which was extensively present in the Levant during MIS 3 (Miebach et al., 2019), is preferred by this species (Khosravi et al., 2016). Overall, the presence of different faunal elements conforms to their requirements and the conditions offered by the landscape.

The modelled visuospatial characteristics of Early Ahmarian sites in the study area indicate the choice of locations with a particular focus on the hunted prey. Sites 
containing species associated with the mixed and patchy environment of the Mediterranean biome show no clear preference for visuospatial characteristics. Low and high TVS values make up the catchments around the sites indicating variable conditions. This is the case for both $1^{\prime}$ and $5^{\prime}$ visual acuity throughout all the catchment isochrones.

At sites where solely gazelle had been hunted, the situation is different. Here, the close-range visuospatial characteristics ( $5^{\prime}$ visual acuity, $1 \mathrm{~h}$ isochrone) show a clear dominance of landscapes with low general visibility. The visual focus is oriented less towards the distance and into the landscape seeking to gain a large-scale overview but regards the local environment. With increasing distance from the site (2-3-h isochrones), this situation dissolves and all sites of different faunal composition show comparable, relatively low values. The focus on the immediate vicinity could be associated with the local environmental conditions present at many sites in the south of the study area. There, monitoring of large areas for determining prey presence was not suitable and did not necessitate the investment of energy for hunting far away from the camp. Again, with 1' visual acuity (max. $7000 \mathrm{~m}$ ), there is no indication for preference of greater visibility or difference to the other sites.

At locations like Abu Noshra I \& II, Al-Ansab 1, the Wadi al-Hasa sites or Tor Hamar locally high levels of humidity had resulted in the presence of open waters, marshes or at least a great density of plants (Clark et al., 2017; Lieberman, 1995; Phillips, 1988, 1991; Schuldenrein \& Clark, 2001). These conditions could have acted as a magnet, pulling the highly mobile herds of gazella subgutturosa to these patches of lush vegetation. Therefore, the Early Ahmarian hunters had been exploiting their major prey at locations of high predictability. We argue for the hunting of the goitered gazelle at highly humid locations in the dry environment of the southern Levant based on prey predictability by the Early Ahmarian hunter-gatherers. This seems to be contrasted by different choices for site location in the more humid environment of the Mediterranean biome to the Northwest. There, observation of less-clustered fauna seemed important.

\section{Conclusion}

With the site of Al-Ansab 1, a settlement in the context of a relatively humid environment in the eastern escarpments of the Jordanian Rift Valley could be documented. The channelling of faunal mobility by the narrow wadi and its position along a pathway between the Jordanian Rift Valley and the Transjordanian highlands made the location attractive for both Early Modern Humans and their prey.

The visual properties of prehistoric sites form a fundamental basis for economical possibilities in the near and far field (Fig. 13). What can be seen and what cannot be seen is relevant for the decision-making processes of prehistoric hunter-gatherers. Assuming that sites are not randomly placed, choices leading to the specific locations can be encoded in the characteristics of a site. The sites of the Early Ahmarian in the Levant show a pattern of visibility and prey, which could be related to varying hunting strategies interwoven with the prevailing environmental conditions. In the comparably lush environment of the Mediterranean biome, the prey was diverse, 


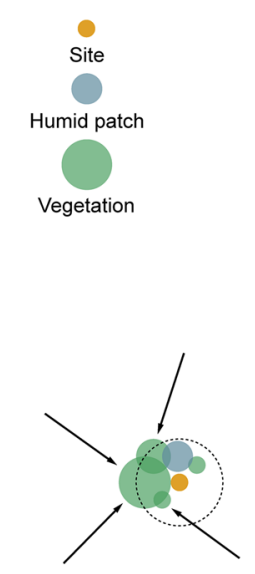

Steppe Biome (Irano-Turanian \& Saharo-Arabian) Visual focus on focus areas Relatively high predictability

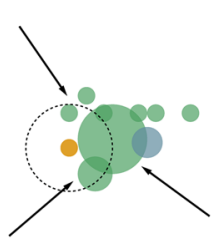

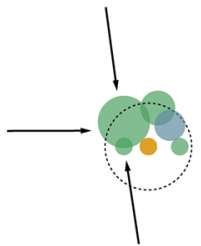

Woodland Biome (Mediterranean)

a $\begin{aligned} & \text { Greater visual coverage } \\ & \text { Relatively low prey predictability }\end{aligned}$

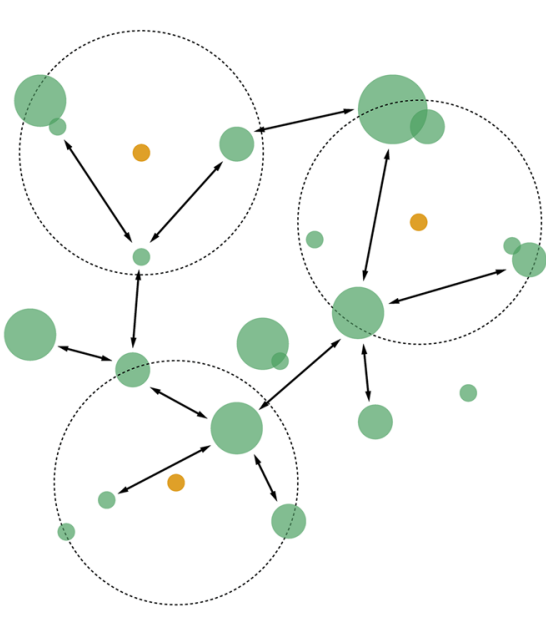

b

Fig. 13 Models of visual conditions and vegetation clustering in steppe and woodland biomes in the study area; clustered vegetation (a, steppe biome) leads to predictable prey presence and visual focus on local conditions; dispersed vegetation (b, woodland biome) leads to low predictability of prey and farfield visual focus

composed of both deer and mountain gazelle. Here, the visual properties of sites were comparable variable, with relatively high far-field visibility. This is contrasted by sites in arid south of the Early Ahmarian contextual area, where Gazella subgutturosa often was the only medium-sized ungulate prey. Here, the visual properties of sites are focused very much on close vicinity. This could be the result of a focus on patches of wetland environment. These acted as magnet locations for gazelles (and likely other faunal resources as well) making their presence predictable at certain times of the year.

\section{Availability of Data and Material}

The datasets generated during and/or analysed during the current study are available from the corresponding author on reasonable request.

Supplementary Information The online version contains supplementary material available at https://oi. org/10.1007/s41982-021-00090-9.

Acknowledgements The results presented here are the outcome of the joint research efforts of the Collaborative Research Centre 806 "Our Way to Europe". We thank the Department of Antiquities (Amman/ Jordan) for granting the excavation permits and Prof. Maysoon Al Nahar from the University of Jordan/ Amman for supporting logistics and student participation. 
Author Contributions All authors contributed to the study conception and design. Material preparation, data collection and analysis were performed by Dr. Florian Sauer and Jonathan Schoenenberg M.A. The first draft of the manuscript was written by Dr. Florian Sauer and all authors commented on previous versions of the manuscript. All authors read and approved the final manuscript.

Funding Open Access funding enabled and organized by Projekt DEAL. This research was funded by the Deutsche Forschungsgemeinschaft (DFG, German Research Foundation) in the Collaborative Research Centre 806 "Our Way to Europe" (Project number 57444011) and the project GEOPAL (Project number 407399340) both based at the University of Cologne.

Code Availability Not applicable.

\section{Declaration}

Conflict of Interests The authors declare no competing interests.

Open Access This article is licensed under a Creative Commons Attribution 4.0 International License, which permits use, sharing, adaptation, distribution and reproduction in any medium or format, as long as you give appropriate credit to the original author(s) and the source, provide a link to the Creative Commons licence, and indicate if changes were made. The images or other third party material in this article are included in the article's Creative Commons licence, unless indicated otherwise in a credit line to the material. If material is not included in the article's Creative Commons licence and your intended use is not permitted by statutory regulation or exceeds the permitted use, you will need to obtain permission directly from the copyright holder. To view a copy of this licence, visit http://creativecommons.org/licen ses/by/4.0/.

\section{References}

Bar-Yosef, O., \& Belfer-Cohen, A. (2004). The Qafzeh upper Paleolithic assemblages: 70 years later. Eurasian Prehistory, 2(1), 145-180.

Bar-Yosef, O., \& Belfer, A. (1977). The Lagaman industry. In O. Bar-Yosef, \& J. L. Phillips (Eds.), Prehistoric Investigations in Gebel Maghara, Northern Sinai (pp. 42-84, Qedem, Vol. 7). Jerusalem: Hebrew University of Jerusalem.

Belfer-Cohen, A., \& Goring-Morris, A. N. (2003). Current issues in Levantine upper Palaeolithic research. In A. Belfer-Cohen \& A. N. Goring-Morris (Eds.), More than meets the eye: Studies on Upper Palaeolithic Diversity in the Near East. (pp. 1-12). Oxbow Books.

Belfer-Cohen, A., \& Goring-Morris, N. (2012). The Earlier Upper palaeolithic: A view from The Southern Levant. In M. Otte, S. Shidrang \& D. Flas (Eds.), The Aurignacian of Yafteh cave and its context. (pp. 127-136). Université de Liège.

Belmaker, M., Arpin, T., \& Stutz, A. J. (2014). Evidence for humid and arboreal environment in the Middle Lisan Basin, 45-39 kya (the Mughr el-Hamamah site, Jordan): Implications for Anatomically Modern Human Dispersal into Western Eurasia. American Geophysical Union Fall Meeting, 2014, PP33D-1269.

Bergman, C. (1988). Ksar Akil and the upper palaeolithic of the Levant. Paléorient, 14(2), 201-210.

Bergman, C., Williams, J., Douka, K., \& Schyle, D. (2017). The Palaeolithic Sequence of Ksar 'Akil, Lebanon. Environments, climate change, and humans. Cambridge University Press, Cambridge.

Bertrams, M. (2013). Late Quaternary landscape evolution in the Wadi Sabra (Jordan) based on sedimentological and geochemical investigations (Aachener geographische Arbeiten, Vol. 49). RWTH Aachen.

Bertrams, M., Protze, J., Eckmeier, E., \& Lehmkuhl, F. (2014). A geochemical approach on reconstructing Upper Pleistocene environmental conditions from wadi deposits-an example from the Wadi Sabra (Jordan). ZeitschriftfürGeomorphologie, Supplementary Issues, 58(1), 51-80.

Besch, D., Oimoen, M., Danielson, J., \& Meyer, D. (2016). Validation of the ASTER Global Digital Elevation Model version 3 over the conterminous United States. In L. Halounova, V. Šafár, J. Jiang, 
H. Olešovská, P. Dvořǎček, D. Holland, et al. (Eds.), Proceedings: XXIII ISPRS Congress, Commission IV (Volume XLI-B4) (Vol. XLI-B4). Prague.

Binford, L. R. (1979). Organization and formation processes: Looking at curated technologies. Journal of anthropological research, 35(3), 255-273.

Bosch, M., Mannino, M., Prendergast, A., Wesselingh, F., O’Connell, T., \& Hublin, J.-J. (2018). Yearround shellfish exploitation in the Levant and implications for Upper Palaeolithic hunter-gatherer subsistence. Journal of Archaeological Science: Reports, 21, 1198-1214.

Bouchud, J. (1974). Etude préliminaire de la faune provenant de la grotte du Djebel Qafzeh près de Nazareth (Israël). Paléorient, 2(1), 87-102.

Brughmans, T., van Garderen, M., \& Gillings, M. (2018). Introducing visual neighbourhood configurations for total viewsheds. Journal of Archaeological Science, 96, 14-25. https://doi.org/10.1016/j. jas.2018.05.006.

Cachel, S. (1997). Deitary Shifts and the European Upper Palaeolithic Transition. Current Anthropology, 38(4), 579-603.

Caracuta, V., Alex, B., Regev, L., Regev, J., Mintz, E., Barzilai, O., et al. (2020). The marine isotope stage 3 landscape around Manot Cave (Israel) and the food habits of anatomically modern humans: New insights from the anthracological record and stable carbon isotope analysis of wild almond (Amygdalus sp.). Journal of Human Evolution, 102868. https://doi.org/10.1016/j.jhevol.2020.102868.

Clark, G., Coinman, N., Hill, J., Neeley, M., Olszewski, D., Peterson, J., et al. (2017). Survey and excavation of Stone Age sites in Jordan's Wadi al-Hasa: 1979-2012. Quaternary of the Levant: Environments, Climate Change, and Humans. Cambridge University Press, Cambridge, 315-328.

Coinman, N. R., \& Henry, D. O. (1995). The Upper Paleolithic sites. In D. O. Henry (Ed.), Prehistoric Cultural Ecology and Evolution. (pp. 133-214). Plenum Press.

Cuckovic, Z. (2016). Advanced viewshed analysis: A quantum GIS plug-in for the analysis of visual landscapes. Journal of Open Source Software, 1(4), 32.

Douka, K., Bergman, C. A., Hedges, R. E., Wesselingh, F. P., \& Higham, T. F. (2013). Chronology of KsarAkil (Lebanon) and implications for the colonization of Europe by anatomically modern humans. PLoS ONE, 8(9), e72931.

Emery-Barbier, A. (1995). Pollen analysis: Environmental and climatic implications. In D. Henry (Ed.), Prehistoric cultural ecology and evolution (pp. 375-384). Springer.

Geffen, H., Perevolotsky, A., Geffen, E., \& Yom-Tov, Y. (1999). Use of space and social organization of female mountain gazelles (Gazellagazellagazella) in Ramat HaNadiv, Israel. Journal of Zoology, 247, 113-119.

Gilead, I. (1983). Upper Palaeolithic occurrences in Sinai and the transition to the Epi-palaeolithic in the Southern Levant. Paléorient, 14(2), 39-53.

Gilead, I. (1984). Palaeolithic sites in northeastern Sinai. Paléorient, 10(1), 135-142.

Gilead, I., \& Bar-Yosef, O. (1993). Early upper Paleolithic sites in the QadeshBarnea area NE Sinai. Journal of Field Archaeology, 20(3), 265-280.

Gladfelter, B. (1997). The Ahmarian tradition of the Levantine Upper Paleolithic: The environment of the archaeology. Geoarchaeology: An Internantional Journal, 12(4), 363-393.

Goode, D., Senior, L., Subah, A., \& Jaber, A. (2013). Groundwater-level trends and forecasts, and salinity trends, in the Azraq, Dead Sea, Hammad, Jordan Side Valleys, Yarmouk, and Zarqa groundwater basins, Jordan. U.S. Geological Survey.

Goring-Morris, N. (1995). Upper Paleolithic occupation of the 'EinQadis region on the Sinai/Negev border. Atiqot, 27, 1-14.

Goring-Morris, N., \& Belfer-Cohen, A. (2018). The Ahmarian in the context of the earlier Upper Palaeolithic in the Near East. In Y. Nishiaki \& T. Akazawa (Eds.), The Middle and Upper PaleolithicArcheology of the Levant and Beyond. (pp. 87-104). Springer.

Goring-Morris, N., \& Davidzon, A. (2006). Straight to the point: Upper PaleolithicAhmarian lithic technology in the Levant. L'Anthropologie, 44(1), 93-111.

Healey, C., \& Sawant, A. (2012). On the limits of resolution and visual angle in visualization. ACM Transactions on Applied Perception, 9(4), 20:21.

Henry, D. (1994). Prehistoric cutural ecology in Southern Jordan. Science, 265, 336-341.

Henton, E., Ruben, I., Palmer, C., Martin, L., Garrard, A., Thirlwall, M., et al. (2018). The seasonal mobility of prehistoric gazelle herds in the Azraq Basin, Jordan: modelling alternative strategies using stable isotopes. Environmental Archaeology, 23(2), 187-199.

Higuchi, T. (1985). The visual and spatial structure of landscapes. Landscape Journal, 4(1), 48-50. 
Hooijer, D. A. (1961). The fossil vertebrates of Ksar'Akil, a Palaeolithic rock shelter in the Lebanon. Brill.

Kerry, K. W., \& Henry, D. O. (2003). Tor Fawaz (J403): An Upper Palaeolithic occupation in the Jebel Qalkha area, southwest Jordan. In A. N. Gorring-Morris \& A. Belfer-Cohen (Eds.), More Than Meets the Eye: Studies on Upper Palaeolithic Diversity in the Near East. (pp. 171-184). Oxbow Books.

Khosravi, R., Hemami, M.-R., Malekian, M., Flint, A., \& Flint, L. (2016). Maxent modeling for predicting potential distribution of goitered gazelle in central Iran: the effect of extent and grain size on performance of the model. Turkish Journal of Zoology, 40, 574-585. https://doi.org/10.3906/ zoo-1505-38.

Klasen, N., Hilgers, A., Schmidt, C., Bertrams, M., Schyle, D., Lehmkuhl, F., et al. (2013). Optical dating of sediments in Wadi Sabra (SW Jordan). Quaternary Geochronology, 18, 9-16.

Kuhn, S. (2004). From Initial Upper Paleolithic to Ahmarian at Üçağizli Cave, Turkey. Anthropologie (1962-), 42(3), 249-262.

Kuhn, S., Stiner, M., Güleç, E., Özer, I., Yılmaz, H., Baykara, I., et al. (2009). The early upper paleolithic occupations at Üçağızlı cave (Hatay, Turkey). Journal of Human Evolution, 56(2), 87-113.

Lengyel, G. (2007). Upper Palaeolithic and Epipalaeolithic Lithic Technologies at Raqefet Cave, Mount Carmel East, Israel. British Archaeological Reports.

Lieberman, D. E. (1995). Cementum increment analyses of teeth from Wadi Judayid (J2) and Tor Hamar (J431): Estimations of site seasonality. In Prehistoric Cultural Ecology and Evolution (pp. 391398): Springer.

Litt, T., Ohlwein, C., Neumann, F. H., Hense, A., \& Stein, M. (2012). Holocene climate variability in the Levant from the Dead Sea pollen record. Quaternary Science Reviews, 49, 95-105.

Mann, H. B., \& Whitney, D. R. (1947). On a test of whether one of two random variables is stochastically larger than the other. Annals of Mathematical Statistics, 18(1), 50-60. https://doi.org/10.1214/aoms/ 1177730491 .

Marks, A., \& Friedel, D. (1983). Prehistoric settlement patterns in the Avdat/Aqev area. In A. Marks (Ed.), Prehistory and Paleoenvironments in the Central Negev, Israel. (Vol. 2, pp. 131-158). Department of Archaeology.

Martin, L. (2000). Gazelle (Gazella spp.) Behavioural ecology: Predicting animal behaviour for prehistoric environments in south-west Asia. Journal of Zoology, 250, 13-30.

Miebach, A., Stolzenberger, S., Wacker, L., Hense, A., \& Litt, T. (2019). A new Dead Sea pollen record reveals the last glacial paleoenvironment of the southern Levant. Quaternary Science Reviews, 214, 98-116. https://doi.org/10.1016/j.quascirev.2019.04.033.

NASA, METI, AIST, Spacesystems, J., \& Team, U. S. J. A. S. (2019). ASTER Global Digital Elevation Model V003 . NASA EOSDIS Land Processes DAAC.

Olszewski, D., \& Schurmans, U. (2007). Raw material use in West-Central Jordan. In C. Delage (Ed.), Chert availability and prehistoric exploitation in the Near East. (pp. 164-203). John and Erica Hedges.

Parow-Souchon, H. (2020). The Wadi Sabra (Jordan) (Kölner Studien zur Prähistorischen Archäologie, Vol. 11). Rahden/Westfalen: Marie Leidorf.

Parow-Souchon, H., \& Purschwitz, C. (2020). Variability in chert raw material procurement and use during the Upper Paleolithic and Early Neolithic of the southern Levant: A regional perspective from the Greater Petra area. Journal of Archaeological Science: Reports, 29, 102087.

Pastoors, A., Weniger, G.-C., \& Kegler, J. F. (2008). The Middle-Upper Palaeolithic transition at Yabroud II (Syria). A re-evaluation of the lithic material from the Rust excavation. Paléorient, 47-65.

Phillips, J. (1988). The Upper Paleolithic of the WadiFeiran Southern Sinai. Paléorient, 14(2), 183-200.

Phillips, J. (1991). Edge-wear, refitting, and ChaînesOpératoires: A case study from Sinai. Meignen L. (Hrsg.), 25, 305-317.

Ploux, S., \& Soriano, S. (2003). Umm el Tlel, une séquence du Paléolithique supérieur en Syrie centrale. Industries lithiques et chronologie culturelle. Paléorient, 5-34.

Piontek, J., \& Vancata, V. (2012). Transition to agriculture in Central Europe: Body size and body shape amongst the first farmers. InterdisciplinariaArchaeologica, 3(1), 23-42.

QGIS, D. T. (2020). QGIS Geographic Information System: Open Source Geospatial Foundation.

Rabinovich, R. (2003). The Levantine Upper Palaeolithic Faunal Record. In N. Goring-Morris, A. BelferCohen, \& J. Riel-Salvatore (Eds.), More than meets the eye. (pp. 33-48). Oxbow Books. 
Rabinovich, R. (2017). The Archaeozoological record in a changing environment of the Late Middle to the Late Pleistocene. In Y. Enzel \& O. Bar-Yosef (Eds.), Quaternary of the Levant: Environments, climate change, and humans. (pp. 347-354). Cambridge University Press.

Richter, J., Hauck, T., Vogelsang, R., Widlok, T., Le Tensorer, J.-M., \& Schmid, P. (2012). "Contextual areas" of early Homo sapiens and their significance for human dispersal from Africa into Eurasia between $200 \mathrm{ka}$ and $70 \mathrm{ka}$. Quaternary International, 274, 5-24.

Richter, J., Litt, T., Lehmkuhl, F., Hense, A., Hauck, T. C., Leder, D. F., et al. (2020). Al-Ansab and the Dead Sea: Mid-MIS 3 archaeology and environment of the early Ahmarian population of the Levantine corridor. PLoS ONE, 15(10), e0239968.

Sauer, F., \& Riede, F. (2018). A critical reassessment of cultural taxonomies in the Central European Late Palaeolithic. Journal of Archaeological Method and Theory, 26, 1-30.

Schuldenrein, J., \& Clark, G. (2001). Prehistoric landscapes and settlement geography along the WadiHasa, West-Central Jordan.PArt I: Geoarchaeology, human palaeoecology and ethnographic modelling. Environmental Archaeology, 6, 23-38.

Schyle, D., Richter, J., \& Bertrams, M. (2015). Pleistocene Archaeology of the Petra Area in Jordan. (Vol. 5). Verlag Marie Leidorf.

Shea, J. (2014). Sink the Mousterian? Named stone tool industries (NASTIES) as obstacles to investigating hominin evolutionary relationships in the Later Middle Paleolithic Levant. Quaternary International, 350, 169-179.

Shea, J., Stutz, A. J., \& Nilson-Stutz, L. (2019). An Early Upper Palaeolithic stone tool assemblage from Mughr El-Hamamah, Jordan: An interim report. Journal of Field Archaeology, 44(7), 420-439.

Stiner, M. C. (2005). The Faunas of Hayonim Cave (Israel): A 200,000-year record of Paleolithic diet, demography and society. . Peabody Museum of Archaeology and Ethnology.

Stiner, M. C. (2009). Prey choice, site occupation intensity \& economic diversity in the Middle-early Upper Palaeolithic at the Üçağılı ${ }_{1}$ Caves, Turkey. Before Farming, 3, 1-21.

Taha, T. K., Rashas, A. M. A., Mahdy, A. E., Aziz, M. A., \& Badran, A. E. (2018). Effect of sex and age on body weight and some morphometric measurements of gazelle dorcas and reedbuck in the Sudan. Journal of Animal, Poultry \& Fish Production, 7(1), 17-24.

van Wagtendonk, J. W., \& Benedict, J. M. (1980). Travel time variation on backcountry trails. Journal of Leisure Research, 12(2), 100-106.

Watts, R. D., Compton, R. W., McCammon, J. H., \& Ouren, D. S. (2003). Intensity of human use, backcountry roads, and analysis of human accessibility. UC Davis: John Muir Institute of the Environment.

Wheatley, D., \& Gillings, M. (1999). Vision, perception and GIS: Some notes on the development of enriched approaches to the study of archaeological visibility. In G. Lock (Ed.), Beyond the map. Archaeology and Spatial Technologies. IOS Press.

Williams, J. K. (2000). Land use and technological trends in the Levantine Upper Paleolithic. MitekufatHaeven, 30, 33-47.

Wronski, T., Sandouka, M., Plath, M., \& Cunningham, P. (2010). Differences in secualdimporhpism among four gazelle taxa (Gazella spp.) in the Middle East. Animal Biology, 60, 395-412.

Yeshurun, R., Schneller-Pels, N., Barzilai, O., \& Marder, O. (2019). Early Upper Paleolithic subsistence in the Levant: Zooarchaeology of the Ahmarian-Aurignacian sequence at Manot Cave, Israel. Journal of Human Evolution. https://doi.org/10.1016/j.jhevol.2019.05.007.

Ziffer, D. (1978). A re-evaluation of the Upper Palaeolithic industries at Kebara Cave and their place in the Aurignacian culture of the Levant. Paléorient, 4, 273-293.

Zohary, M. (1962). Plant life of Palestine: Israel and Jordan. Israel and Jordan.

Publisher's Note Springer Nature remains neutral with regard to jurisdictional claims in published maps and institutional affiliations. 